\title{
ECONOMIC AND LEGAL ASPECTS AGAINST CONTROLLING GOODS TURNOVER
}

\author{
Ruslan Fyl', Galina Luk'yanova ${ }^{2}$
}

\begin{abstract}
The purpose of this article is to describe the content of the economic and legal bases of counteraction to the circulation of counterfeit goods. Using systemic and formal-logical methods, the amount of economic losses is outlined and the magnitudes of consequences arising from the circulation of counterfeit goods for the state, patent holders, consumers and manufacturers of counterfeits are outlined. It has been stated that drugs, toys, agrochemicals, and foodstuffs are the most counterfeit at the moment and are not only supported by crime as a crime in the field of intellectual property, but also endanger the lives and healths. Considering the market of counterfeit goods described its features, which are that the operation indicated the author but due to factors such as low solvency of the population in developing countries; the inability to sell counterfeit products separately from the original products, due to the fact that the original products are used for masking in the sale of counterfeiting; lack of specialized equipment for establishing counterfeit goods and knowledge of the original; scale and narrow specialization of counterfeit goods market participants; the transnational nature of this market; splicing organized crime with law enforcement agencies; high profitability of counterfeit market. The practical importance of the research is the documentary analysis examines the international legal aspects of counterfeiting of such goods and notes that the rules of the Agreement on Trade-Related Aspects of Intellectual Property Rights, TRIPS and the EU Customs Regulation on Intellectual Property Observance set out measures to combat trafficking in goods that infringes intellectual property rights. Consequently, successfully tackling counterfeit goods trafficking requires a constant search for innovative methods of struggle. An effective strategy for overcoming this phenomenon should combine the various measures of its counteraction, all of them should be used in a coordinated and systematic way, complementing each other. Therefore, both economic and political management methods must be taken into account to overcome the counterfeit. And only their optimal combination will have the greatest effect in the formation of concepts of counteraction to the circulation of counterfeit goods. And this is definitely worth the effort since the innovative and economic development of the state depends on solving the problem of creating an effective system of protection of intellectual property rights. Methodology. A methodological framework of the economic and legal bases of counteraction to the circulation of counterfeit goods is defined by the complex of scientific cognition methods that allow us to look at this problem as a multi-aspect, interdisciplinary phenomenon. On the basis of the system, structural, systemic-functional and other scientific approaches, the idea of counteraction to the circulation of counterfeit goods has formed a complex systemic category covering the theoretical and practical level of economic and legal activity.
\end{abstract}

Key words: counterfeit goods, illicit trafficking, infringement of intellectual property rights, copyright holder, consumer, forgery.

JEL Classification: M38, K11, K23

\section{Introduction}

In recent years, counterfeiting has become particularly widespread. The possibility of gaining surplus pushes unscrupulous manufacturers of counterfeit goods, importers and exporters for violation of the law. For the sake of profit, they manufacture counterfeit products of global brands, while neglecting quality standards and consumer safety. Illicit trafficking in counterfeit goods leads to a decrease in revenues to the state and local budgets, undermines the intellectual capacity of the state and slows down the development of science and culture. Therefore, the solution of the problem of creating effective means of combating counterfeit goods depends on the strength of the innovative model

Corresponding author:

${ }^{1}$ State Research Institute of Ministry of Internal Affairs of Ukraine, Ukraine.

E-mail: ruslan.sn111@gmail.com

${ }^{2}$ Lviv Polytechnic National University, Ukraine.

E-mail: bnp1969@ukr.net 
of state development, its modernization, increasing the competitiveness in the world socio-economic system, as well as the creation of jobs in new industries that determine the state of the world economy of the XXI century. This also applies to the creation of a civilized market where developers, manufacturers, and consumers would be reliably protected from unfair competition related to the misuse of intellectual property rights and the production of counterfeit goods.

Unlike forgery, counterfeit can be of very good quality. Forgery items are goods of very low quality, which are given out as the original. However, in any case, this deprives the owners of brand revenue, since the originals are replaced with fakes. Sometimes the frequent mention of the brand name dramatically reduces not only the total brand revenue but also is detrimental to quality and image. Moreover, most companies in the world suffer from this. All products of well-known brands that are in great demand are forged in export markets.

All that can be done is to impose a fine, but most often its size does not cover even $10 \%$ of the losses from the very fact that counterfeit appeared on the market of goods and services. Legislators are constantly looking for mechanisms to tighten measures for violators, but the way of their performance have not been decided yet. There are dozens of anti-counterfeiting agencies in Western Europe and the USA that specialize in the area of legal assistance. In Ukraine, this area has not been developed yet. Despite this, the accumulated experience allows us to offer solutions, the implementation of which is quite possible even for small and medium-sized enterprises.

\section{Economic losses and consequences from the circulation of counterfeit goods}

According to the Organization for Economic Cooperation and Development (OECD) data, food, medicines, and toys are the most counterfeit today (Mapping the Economic Impact, 2016). The existence of such a market is a socially dangerous phenomenon because it contributes to the flourishing of not only poor quality, but also dangerous products for human life and health. In Ukraine, the production and sale of counterfeit goods are observed in almost all segments. Light industry (clothing, footwear, bags, etc.), pharmaceutical, chemical, perfumery and cosmetology, food industry (alcohol and tobacco) and construction materials, which are constantly informed by the media, suffer most from counterfeiting.

The increasing circulation of counterfeit medicines every year is causing significant losses to the pharmaceutical industry, which is constantly confirmed by the data of international organizations. For example, in 2017, in the result of the annual operation Pangea $X$ (2017) (the international week of fighting online sales along with the Internet counterfeit, medicines and medical devices), conducted by Interpol in cooperation with the public persons, police, healthcare community, and private sector representatives from the pharmaceutical industry from around the world, 25 million counterfeit drugs and illicit drugs worth over $51 \mathrm{mln}$. USD and medical devices worth about 500 thous. USD were seized. Among the removed were: supplements, painkillers, and antiepileptic drugs, drugs for the treatment of erectile dysfunction, antipsychotics, food, dental devices and implants, condoms, syringes, medical test strips, and surgical equipment.

According to the OECD report (2016), the global market for counterfeit goods in 2013 was estimated at 461 billion USD. Of these, the EU counterfeit and pirated products account for about $7 \%$ of its imports, or $121 \mathrm{bln}$. EUR a year. At the same time, from 2011 to 2013 the share of counterfeit goods in imports was $20 \%$ for the USA, $15 \%$ for Italy, $12 \%$ for France and Switzerland, 8\% for Japan and Germany, 4\% for Great Britain, 3\% for Luxembourg.

For example, in Ukraine in 2018, the turnover of counterfeit products, according to the European Business Association, amounted to about $1 \mathrm{bln}$. USD, including coffee $40 \%$ alcohol $60 \%$, agrochemical products $25 \%$, household appliances, and electronics to certain categories from $50 \%$ to $70 \%$ (EU-Ukraine Dialogue on Intellectual Property Rights, 2019). In general, almost $40 \%$ of pesticides imported to Ukraine are made in China, $20 \%$ of which are counterfeit (Ukraine Business Online, 2012). Counterfeit pesticides not only violate intellectual property rights, destroy fields, destroy farmers' crops, but also threaten the ecosystem not only of Ukraine but also of neighboring countries. Therefore, non-compliance with international quality standards in the agrochemical field poses the threat of large-scale man-made disasters.

Due to the high volume of counterfeit goods, its effects also become significant. For the state, these effects are reflected in the reduction of tax revenues from the patent holders, as the sales of their original goods are reduced in favor of counterfeiting and the allocation of additional funds to counteract the counterfeit or the imposition of penalties due to the high level of counterfeiting in the state. Neglecting such a problem, for example, for Ukraine 2001 ended with being on the Special 301 list and paying $75 \mathrm{mln}$. USD of annual fines. In 2011 more than 140 commodities were excluded from the international assistance programs for developing countries and the duty-free export of goods to the most developed countries of the world (Mapping the Economic Impact, 2016). Consumers can seriously harm their own health and safety by buying counterfeit medicines, toys, spare parts for cars and other counterfeit goods. A. B. Plowman NCB notes that customers should realize that by purchasing counterfeit they support crime and endangering the life and health (Ukrainians are urged not to buy counterfeit products, 
2019). Manufacturers of the counterfeitings cause significant harm to the owners of intellectual property, not only because of their failure to pay royalties for the use of the intellectual property rights but the decrease in sales and damage to their image and reputation.

\section{Features of the market for counterfeit goods}

The OECD market for counterfeit goods is divided into primary and secondary. The primary market is characterized by the fact that the consumer buys counterfeit products ill-advisedly, and secondary is where the consumer, on the contrary, buys counterfeit deliberately and intentionally. In this context, this market has its own peculiarities.

Usually, in developing countries, the majority of the population is unable to purchase original goods due to financial insolvency that stimulates the development of counterfeit goods. Therefore, the development of the counterfeit market depends directly on the purchasing power of the population. Low consumer awareness of the original product and the lack of specialized equipment for detecting counterfeit products also leads to increased production of counterfeit goods worldwide. Moreover, the existence of counterfeit in related to the sale is of the impossibility of fake products apart from the original, because the original acts to implement disguise counterfeit. Currently, the volume of counterfeit goods at several times the amount of the respective original product. The leader in the People's Republic of China, which is 2013, together with its Hong Kong Special Administrative Region, produced almost $84.5 \%$ of the world's counterfeits. A similar situation was repeated in the period of 2011-2012, where the percentage of counterfeit Chinese goods on the world market was $77.08 \%$ and $83.11 \%$ respectively. In addition to China, counterfeit suppliers include emerging economies, including Turkey, Thailand, Singapore, India, the United Arab Emirates, Morocco, Suriname, and Greece. Most often, these countries forge consumer goods: clothing, shoes, accessories, toys, products, and medicines (Economics.lb.ua, 2013). These questions are sufficiently described in the work of the Professors Tylchyk O., Tylchyk V. (2018).

The existence of the counterfeit goods market is further due to the fact that the counterfeit goods are the result of excess production of the original goods under the license of the customer-right holder. Because most of the counterfeit market participants are unaware of the unlawfulness of the actions taken, the way major manufacturing operations are performed at large enterprises within the scope of formal agreements.

This market is characterized by its large scale and transnational character. The availability of cheap labor, productive resources, access to minerals and financial instruments now contributes to the full lifecycle of counterfeit goods within a single country. On the contrary, to involve in a number of countries in the implementation of a counterfeit, one of them will be a transit, or producer, or consumer.

From the structure of organized crime, which controls the market of counterfeit products in the countries of South and Central America, Western Europe, as well as Israel, China, Japan, Russia, Ukraine, has its own peculiarities. Recent trends indicate a transformation of the previously established hierarchy of national associations in a flexible transnational network structure which is adapted also for committing economic crimes.

In addition, for the proper functioning of the market for counterfeit goods, there is an increase in organized crime with the controlling and law enforcement agencies. In this case, there is a symbiosis in which corruption supports the growth of the shadow economy and economic crime, which, in turn, stimulate its increase.

\section{Counteraction of counterfeit goods}

The international legal factors for counteracting counterfeiting are the provisions of the Agreement on Trade-Related Aspects of Intellectual Property Rights, TRIPS and the EU Regulation No. 608/2013 on Customs Enforcement of Intellectual Property Rights, terminating the validity of EU Council Regulation 1383/2003.

Intellectual property plays an important role in international trade, accounting for about $2 \%$ of all world trade, mostly regulated by the World Trade Organization (WTO). One of the most important WTO agreements is the TRIPS Agreement (2010), the legal rules of which contain requirements for measures to combat the circulation of counterfeit goods. Yes, Art. 61 of the Agreement requires that fair and equitable procedures be established for all intellectual property rights, which will not be unduly burdensome, complex or costly, and will not be limited in time of action. In view of the damage caused by counterfeit goods, which is a manifestation of infringement of intellectual property rights, the TRIPS Agreement provides for urgent measures to protect the rights, including preliminary or temporary, without notifying the suspected infringer. The defense procedures, as noted by Lonh D., Rey P., and others (2007) must be adopted on the basis of the evidence presented by the parties, in addition, to impartial judges.

The provisions of the TRIPS Agreement (2010) provide for administrative, criminal remedies for counterfeit goods. Therefore, in the case of intentional falsification of a trademark or copyright infringement on a commercial scale, Member States should ensure that criminal proceedings and penalties are applied. Measures the Punishment should include imprisonment and/or monetary penalties sufficient to serve as a deterrent to the level of punishment applied in cases of serious crime. In some cases, penalties should also include the arrest, seizure, and destruction of infringing goods and any material or equipment that was used to 
a large extent in the commission of the infringement. In addition, the members of this Agreement may provide for criminal proceedings and penalties in other cases of infringement of intellectual property rights, especially when committed intentionally and commercially.

Analyzing the disposition of Art. 61 Agreement TRIPS, K. D. rapid paradise concludes that effective combating counterfeit goods consist of two main elements: an efficient search and seizure of counterfeit goods without notifying law enforcement agencies offenders (raids); the existence in the legislation of punishment measures that prevent the violation of rights, and their application in practice by the judicial authorities (Bystray, 2012).

The TRIPS Agreement establish these rules and mechanism to combat counterfeit drugs, to protect the economic interests of stakeholders and further encourage pharmaceutical research, but also provide protection from serious health threats arising from the use of counterfeit drugs.

The application of administrative procedures at the customs border to prevent the movement of counterfeit goods across the customs border is defined in Sec. $4 \ll$ Specific requirements for border actions $\gg$ of the TRIPS Agreement. This section sets out the legal mechanism for customs protection of intellectual property rights for each WTO member country to designate a competent authority that, at the discretion of each member, can be both administrative and judicial, to which the right holder may apply customs procedures for the protection of intellectual property rights.

In order to close access to the markets for counterfeit goods, to control illegal trade without harming the legal and customs clearance of counterfeiting, the EU adopted Regulation No 608/2013 (2013) which establishes a unified approach to customs protection of intellectual property rights and influences national legislation, the EU legal framework in the field of intellectual property and the laws of the Member States governing criminal proceedings. This cannot be said about the amount and type of administrative penalties for violation of customs rules when moving counterfeit goods. This is a question that each country decides on its own.

The EU Regulation No 608/2013 defines the basic conditions and procedures for action by European customs authorities in the case of the movement of goods that are suspected of infringing intellectual property rights or are subject to customs surveillance or customs control in the customs territory of the EU.

\section{Conclusions}

Summing up, we come to the conclusion that the created market of counterfeit goods is a set of shadow socio-economic relations that arise as a result of the illicit circulation of products, which is protected by special legislation in the field of intellectual property. The objects of this market can be not only counterfeit goods, falsified products, but also original products made with breach of a license agreement or sold with breach of contract. Ignoring counterfeiting of such goods harms not only the owner of the original product, but also consumers who, by purchasing counterfeit goods of poor quality, endanger their lives and health, and the state as a whole, which loses budget revenues from patentees and the imposition of penalties because of the high level of counterfeiting in its territory.

In general, in today's economy, the counterfeit goods market is successfully functioning as a manifestation of the inability of a competitive market for intellectual products. This also indicates that the market for original products can exist only if the state regulates the circulation of counterfeits.

Also, a significant role in the strategy of counteracting the trafficking of counterfeit goods belongs to the rights holders of the original products, who, using the system of the legal protection of intellectual property rights established by the state, could properly protect their rights and promptly fight against violators of their rights. In addition, manufacturers of legal goods should adhere to the rational pricing of their products, which would really take into account the level of consumer income in the market where the sale of goods occurs.

Consequently, successfully tackling counterfeit goods trafficking requires a constant search for innovative methods of struggle. An effective strategy for overcoming this phenomenon should combine the various measures of its counteraction, all of which should be used in a coordinated and systematic way, complementing each other. Therefore, both economic and political management methods must be taken into account to overcome the counterfeit. And only their optimal combination will have the greatest effect in the formation of concepts of counteraction to the circulation of counterfeit goods. And this is definitely worth the effort since the innovative and economic development of the state depends on solving the problem of creating an effective system of protection of intellectual property rights.

\section{References:}

Agreement on Trade-Related Aspects of Intellectual Property Rights of (dated April 15, 1994). Official Bulletin of Ukraine (2010). № 84. P. 503. Art. 2989.

Bystray, K. D. (2012). Kryminal'no-pravova okhorona tovarnoho znaku v mizhnarodnomu pravi [Criminal and Legal Protection of a Trademark in International Law]. International Readings on International Law in Memory of Professor P. Kazansky: Mater. the third International. Sciences. Conf. (Odesa, 2-3 March). Odesa: Phoenix, pp. 176-178. (in Ukrainian) 
Lonh, D., Rey, P., Zharov, V. O., Sheveleva, T. M., Vasylenko, I. E., and others (2007). Zakhyst prav intelektual'noyi vlasnosti: normy mizhnarodnoho i natsional' noho zakonodavstva ta yikh pravozastosuvannya: prakt. posib. [Protection of Intellectual Property Rights: Norms of International and National Legislation and their Application: Pract. textbook]. Kyiv: K.I.S, 448 p. (in Ukrainian)

Pangea X: vylucheno blyzko $25 \mathrm{mln}$ kontrafaktnykh likiv na sumu blyz'ko $51 \mathrm{mln}$ dol. SSHA (2017). [Pangea X: About 25 million counterfeit medicines worth about \$ 51 million seized USA]. Retrieved from: https://www.apteka.ua/article/427651 (accessed 10 November 2019). (in Ukrainian)

Poteri ekonomiki Ukrainy ot kontrafakta ocenili v $€ 1 \mathrm{mlrd}$ (2013). [The losses of the Ukrainian economy from the counterfact were estimated at $€ 1$ billion]. Retrieved from: http://economics.lb.ua/state/2013/04/26/198195 poteri_ekonomiki_ukraini.html (accessed 10 November 2019). (in Russian)

Pashko, P., Tylchyk, O., \& Kotukha, O. (2018). Ontology of scientific cognition of shadow economy and economic shading. Baltic Journal of Economic Studies, vol. 4, no. 2, pp. 151-158. doi: 10.30525/2256-0742/2018-4-2-151-158 Tylchyk, O., Pluhatar, T., \& Kotukha, O. (2018). Determinants of shadowing of the economy: the genesis of economic and legal doctrines. Baltic Journal of Economic Studies, vol. 4, no. 3, pp. 302-308. doi: 10.30525/22560742/2018-4-3-302-308

Tylchyk, O., Dragan, O., \& Nazymko, O. (2018). Establishing the ratio of concepts of counteraction to legalization (laundering) of illegally-obtained income and counteraction to the shadow economy: the importance for determining performance indicators of the European integration processes. Baltic Journal of Economic Studies, vol. 4, no. 4, pp. 341-346. doi: 10.30525/2256-0742/2018-4-4-341-345

Tylchyk, O. Riabchenko, Y., \& Popivniak, O. (2018). Management (administrative) activity of the controlling authorities in the area of taxation: essence and types. Baltic Journal of Economic Studies, vol. 4, no. 5, pp. 343-351. doi: $10.30525 / 2256-0742 / 2018-4-5-343-351$

Tylchyk, V., Bielai, S., \& Morozov, I. (2018). The innovative approach to the crisis situations monitoring of the social and economic origin that endanger the security of Ukraine. Baltic Journal of Economic Studies, vol. 4, no. 3, pp. 15-21. doi: 10.30525/2256-0742/2018-4-3-15-21

Tylchyk, V., Jankovska, L., \& Khromyshin, I. (2018). National economic security: economic and legal framework for ensuring in the conditions of the European integration. Baltic Journal of Economic Studies, vol. 4, no. 1, pp. 47-56. doi: $10.30525 / 2256-0742 / 2018-4-1-350-357$

Regulation (EU) № 608/2013 of the European Parliament and of the Council of 12 June 2013 concerning customs enforcement of intellectual property rights and repealing Council Regulation (EU) № 1383/2003. Official Journal of the European Union. 29 June 2013. № L 181, pp. 15-34.

Trade in Counterfeit and Pirated Goods: Mapping the Economic Impact. Retrieved from: http://www.oecd.org/ governance/trade-in-counterfeit-and-pirated-goods-9789264252653-en.htm (accessed 10 November 2019).

Ukraine, China to combat poor-quality agrochemicals conjointly. Ukraine Business Online (2012). Retrieved from: http://www.ukrainebusiness.com.ua/news/4941.html/ (accessed 10 November 2019)

Ukrayina maye aktyvizuvaty zusyllya shchodo borot'by z piratstvom ta pidrobkamy - Dialoh mizh YES ta Ukrayinoyu shchodo prav intelektual'noyi vlasnosti [Ukraine needs to step up its efforts to combat piracy and counterfeiting - the EU-Ukraine Dialogue on Intellectual Property Rights]. Retrieved from: https://eeas.europa.eu/ delegations/ukraine/64968/ (accessed 10 November 2019). (in Ukrainian)

Ukrayintsiv zaklykayut ne kupuvaty kontrafaktnu produktsiyu [Ukrainians are urged not to buy counterfeit products]. Retrieved from: https://www.ukrinform.ua/rubric-society/2728078-ukrainciv-zaklikaut-ne-kupuvatikontrafaktnu-produkciu.html (accessed 25 June 2019). (in Ukrainian) 